\title{
Repatriations of human remains from Germany - 1911 to 2019
}

\author{
Andreas Winkelmann
}

\begin{abstract}
While occasional earlier restitutions of colonially acquired human remains, mostly skulls, from German anthropological collections to source communities went largely unnoticed, it seems that such repatriations have 'taken off' since the hand-over of 20 skulls to a Namibian delegation in 2011. It is, however, difficult to get a comprehensive overview of these events, given the German federal system and the diversity of institutions involved. Moreover, there is no standard as to how much provenance research should be conducted before returning human remains and how much detail should be published, if at all. This article reviews repatriations of human remains from German institutions and related publications. It argues for authors and institutions to publish and publicize these events and related research more widely. It also looks at the variability of the political context of these processes and argues for more direct, i.e. government-independent contacts between collecting institutions and source communities.
\end{abstract}

Key words: repatriation, human remains, provenance research, colonial collections

\section{Introduction}

The last few years have seen a dramatic increase of repatriations of human remains from Germany to Indigenous communities. Some of them received wide publicity, like for example, the first handover of 20 skulls of colonial origin to a Namibian delegation in 2011, but others went largely unnoticed. This article gives an overview of repatriations of human remains and related publications from German institutions until April 2019. A list of such events will be followed by an analysis of these repatriations and the returned human remains, and an interpretation and discussion of some emerging aspects.

A short note on terminology: the commonly used term 'repatriation' has its flaws. It is based on the concept of 'patria', fatherland, i.e. a male concept that excludes, as it were, 'rematriation'. Moreover, it may have a negative, chauvinist ring to it, at least in Germany where patriotism is historically connected to the initiation of two world wars (Winkelmann 2020). On the other hand, 'repatriation' does allude to a common motivation for requests to have human remains returned 'home', that is, the special connection of people to their native land. The term 'restitution', on the other hand, has the disadvantage that it may suggest going back to a previous state of things, i.e. to change the past - something that is simply not possible. 'Reburial' does not include the act of handing over, and does not apply to all cases. I therefore mostly use 'repatriation' here, as it is the established term to designate the restitution or return of items from colonial collections to source communities and is also used in national laws like the 'Native American Graves Protection and Repatriation Act' (Fründt 2013: 328).

\section{Repatriations from Germany}

Table 1 lists all identified repatriations of human remains from Germany. I cannot exclude, however, that other repatriations have gone unnoticed and the information I have gathered is incomplete. 


\begin{tabular}{|c|c|c|c|c|c|}
\hline Year & Institution & $\begin{array}{l}\text { Number of } \\
\text { indivduals }\end{array}$ & Community & Nation & References \\
\hline 1911 & $\begin{array}{l}\text { Royal Ethnological } \\
\text { Museum Berlin }\end{array}$ & 2 & $?$ & Samoa & Zimmerman 2001: 161 \\
\hline 1954 & $\begin{array}{l}\text { Übersee-Museum } \\
\text { Bremen }\end{array}$ & 1 & Hehe & Tanzania & Baer and Schröter 2001* \\
\hline 1978 & $\begin{array}{l}\text { Göttingen } \\
\text { University }\end{array}$ & 2 & Shuar & Ecuador & $\begin{array}{l}\text { Magisches Einsatzkommando der } \\
\text { Deutschen Gesellschaft für } \\
\text { Völkerkunde } 1978\end{array}$ \\
\hline 1991 & $\begin{array}{l}\text { Ethnological } \\
\text { Museum Hamburg }\end{array}$ & 1 & Maori & $\begin{array}{l}\text { New } \\
\text { Zealand }\end{array}$ & Te Papa Museum 2011: 5 \\
\hline 2006 & $\begin{array}{l}\text { Übersee-Museum } \\
\text { Bremen }\end{array}$ & 2 & Maori & $\begin{array}{l}\text { New } \\
\text { Zealand }\end{array}$ & $\begin{array}{l}\text { Fründt and Förster 2018; Herewini } \\
2008\end{array}$ \\
\hline 2011 & Charité Berlin & 20 & Herero, Nama & Namibia & $\begin{array}{l}\text { Stoecker and Winkelmann 2018*; } \\
\text { Winkelmann } 2012\end{array}$ \\
\hline 2011 & $\begin{array}{l}\text { Institute of } \\
\text { Anatomy Bonn }\end{array}$ & 1 & Krenak & Brasil & \\
\hline \multirow[t]{2}{*}{2011} & $\begin{array}{l}\text { Senckenberg } \\
\text { Museum Frankfurt }\end{array}$ & 1 & Maori & $\begin{array}{l}\text { New } \\
\text { Zealand }\end{array}$ & Te Papa Museum 2011: 4 \\
\hline & $\begin{array}{l}\text { Weltkulturen } \\
\text { Museum Frankfurt }\end{array}$ & 1 & Maori & \begin{tabular}{|l|} 
New \\
Zealand
\end{tabular} & Te Papa Museum 2011: 5 \\
\hline 2012 & Charité Berlin & 1 & Aché & Paraguay & Koel-Abt and Winkelmann 2013* \\
\hline 2012 & $\begin{array}{l}\text { State Ethnological } \\
\text { Museum Munich }\end{array}$ & 1 & $?$ & Peru & \\
\hline 2013 & Charité Berlin & 33 & Aborigine & Australia & $\begin{array}{l}\text { Winkelmann 2020*; Winkelmann } \\
\text { and Teßmann 2013** }\end{array}$ \\
\hline 2014 & Charité Berlin & 21 & $\begin{array}{l}\text { Damara, } \\
\text { Herero, Nama, } \\
\text { Ovambo, San }\end{array}$ & Namibia & $\begin{array}{l}\text { Stoecker and Teßmann } 2013^{\star} ; \\
\text { Stoecker and Winkelmann 2018*; } \\
\text { Winkelmann and Stoecker } 2014\end{array}$ \\
\hline 2014 & Charité Berlin & 14 & $\begin{array}{l}\text { Aborigine, } \\
\text { Torres Strait } \\
\text { Islander }\end{array}$ & Australia & Winkelmann $2020^{*}$ \\
\hline 2014 & Charité Berlin & 1 & $\begin{array}{l}\text { Tasmanian } \\
\text { Aborigine }\end{array}$ & Australia & Winkelmann and Teßmann 2018* \\
\hline 2014 & Freiburg University & 14 & $\begin{array}{l}\text { Herero, Nama, } \\
\text { Damara }\end{array}$ & Namibia & $\begin{array}{l}\text { Möller 2015[2008]; Wittwer- } \\
\text { Backofen et al. 2014* }\end{array}$ \\
\hline 2014 & private & $1^{\star \star}$ & Hehe & Tanzania & Brockmeyer 2018 \\
\hline \multirow[t]{3}{*}{2017} & Charité Berlin & 1 & Aborigine & Australia & Winkelmann $2020^{*}$ \\
\hline & BGAEU & 1 & Ngadjon & Australia & \\
\hline & $\begin{array}{l}\text { Senckenberg } \\
\text { Gesellschaft für } \\
\text { Naturforschung } \\
\text { Frankfurt }\end{array}$ & 1 & Aborigine & Australia & Schrenk et al. 2018: 51 \\
\hline 2017 & $\begin{array}{l}\text { Übersee-Museum } \\
\text { Bremen }\end{array}$ & 44 & Maori, Moriori & $\begin{array}{l}\text { New } \\
\text { Zealand }\end{array}$ & \\
\hline 2017 & BGAEU & 1 & Ainu & Japan & \\
\hline 2017 & $\begin{array}{l}\text { State Ethnographic } \\
\text { Collections Saxony }\end{array}$ & 4 & Hawai'i & USA & Ayau and Keeler 2017 \\
\hline 2017 & $\begin{array}{l}\text { Landesmuseum } \\
\text { Hannover }\end{array}$ & 1 & Lamalama & Australia & \\
\hline \multirow[t]{7}{*}{2018} & Charité Berlin & $17^{* *}$ & $\begin{array}{l}\text { Herero, Nama, } \\
\text { Ovambo, San }\end{array}$ & Namibia & Stoecker and Winkelmann $2018^{*}$ \\
\hline & private & 1 & $?$ & Namibia & Ziegenfuß and Rücker 2018* \\
\hline & $\begin{array}{l}\text { Institute of } \\
\text { Anatomy } \\
\text { Greifswald }\end{array}$ & 3 & Herero, Nama & Namibia & \\
\hline & Jena University & 1 & Herero? & Namibia & Förster and Stoecker 2016* \\
\hline & $\begin{array}{l}\text { University Medical } \\
\text { Center Hamburg }\end{array}$ & 1 & $?$ & Namibia & \\
\hline & $\begin{array}{l}\text { DITSL } \\
\text { Witzenhausen }\end{array}$ & 1 & Nama & Namibia & $\begin{array}{l}\text { Hulverscheidt and Stoecker 2018*; } \\
\text { Hulverscheidt et al. 2017* }\end{array}$ \\
\hline & $\begin{array}{l}\text { Landesmuseum } \\
\text { Hannover }\end{array}$ & 3 & Nama & Namibia & \\
\hline 2018 & $\begin{array}{l}\text { Rautenstrauch- } \\
\text { Joest-Museum } \\
\text { Cologne }\end{array}$ & 1 & Maori & \begin{tabular}{|l|} 
New \\
Zealand
\end{tabular} & \\
\hline 2019 & $\begin{array}{l}\text { Fünf Kontinente- } \\
\text { Museum Munich }\end{array}$ & 1 & Yidindji & Australia & Turnbull 2017: 2, 263 \\
\hline \multirow[t]{2}{*}{2019} & $\begin{array}{l}\text { Linden-Museum } \\
\text { Stuttgart }\end{array}$ & 2 & Aborigine & Australia & \\
\hline & Freiburg University & 8 & Aborigine & Australia & \\
\hline \multirow[t]{2}{*}{2019} & $\begin{array}{l}\text { State Ethnographic } \\
\text { Collections Saxony }\end{array}$ & 76 & $\begin{array}{l}\text { Aborigine, incl. } \\
\text { Yawuru }\end{array}$ & Australia & $\begin{array}{l}\text { Schlott 2018; Skyring and Yu } \\
2019^{\star}\end{array}$ \\
\hline & $\begin{array}{l}\text { Institute of } \\
\text { Anatomy Halle }\end{array}$ & 5 & $\begin{array}{l}\text { Aborigine, incl. } \\
\text { Biyaygirri }\end{array}$ & Australia & \\
\hline 2019 & Charité Berlin & 109 & Maori, Moriori & $\begin{array}{l}\text { New } \\
\text { Zealand }\end{array}$ & \\
\hline
\end{tabular}

Table 1. Overview of repatriations of colonially acquired human remains from Germany. If no reference is given, information is from the press or public websites. The number of individuals is sometimes an approximation (see text).

$B G A E U=$ Berliner Gesellschaft für Anthropologie, Ethnologie und Urgeschichte (Berlin Society for Anthropology, Ethnology, and Prehistory). 
DITSL = Deutsches Institut für tropische und subtropische Landwirtschaft (German Institute for Tropical and Subtropical Agriculture, the former "German Colonial School").

* Includes provenance research pertaining to these cases or some of the cases.

** One San individual is counted twice, as the skull was repatriated in 2014, the related skeleton in 2018. The same is true for one tooth returned in 2014 belonging to Mkwawa's skull returned in 1954 (see text).

Arguably, the first return of human remains from Germany to their place of origin took place in 1911. As Andrew Zimmerman (2001: 161) already described in passing, Felix von Luschan, the curator of the collections of the Königliches Museum für Völkerkunde (Royal Museum of Ethnology) in Berlin (cf. Kunst and Creutz 2013), returned two skulls to Samoa upon the request of a local collector, colonial judge Erich Schultz. A local Samoan chief had noted the theft of remains and feared bad luck if the bones were not in their original place, as Schultz wrote to von Luschan (Schultz 1911). Zimmerman missed, however, that von Luschan returned two different 'damaged skulls' instead, mainly because von Luschan was keen to keep the originals, as he had put much work into their mounting (von Luschan 1911). The remains originally sent from Samoa by Schultz are still in the S-collection in Berlin - the history of repatriations from Germany therefore starts with a fraud. Luschan was certainly not the only 'cheat' in this respect: When, in 1885, in then German South-West Africa, a Nama woman demanded that Waldemar Belck, a German scientist, return the remains of her father, Belck knowingly gave her another skull instead (Förster et al. 2018: 51). As this happened before Belck took the remains to Germany, however, this cannot count as a 'repatriation' from Germany.

The first well-known repatriation from Germany in 1954 is also a special one (Baer and Schröter 2001). In the 1890s, the Hehe (or Wahehe) chief Mkwawa had successfully led resistance to the colonial troops in then 'German East-Africa'. When eventually surrounded in 1898, he shot himself to avoid capture. His skull was apparently taken to Germany by Captain Tom von Prince. At the request of the British, the Treaty of Versailles of 1919 explicitly demanded the return of Mkwawa's skull. However, this only materialized when the then governor of British Tanganyika selected the skull at the Übersee-Museum in Bremen and returned it to the now British colony in 1954 (Baer and Schröter 2001: 193ff). It has since been on display at the Mkwawa Memorial Museum in Kalenga, Tanzania. 50 years later, in a rare sequel, a tooth of Mkwawa that had remained in Germany was returned to Mkwawa descendants by a member of the von Prince family in 2014 (Brockmeyer 2018). The tooth had been worked into a pendant as a kind of family trophy.

The third repatriation, of 1978, is again very special. In a letter of November 1976, representatives of the Shuar in Ecuador had asked the Institute of Ethnology of Georg-August University in Göttingen for the return of one or two shrunken heads (tsantsas) to complete a representation of their cultural heritage in an ethnographic museum in Quito, and offered tsantsas made of sloth heads in exchange. As the director of the Institute had answered this request with an evasive reply, a group of unnamed students felt obliged and justified to take action. They stole two tsantsas from a showcase at the Institute and returned them to the Shuar on their own account. In a student journal, the students, who called themselves 'Magical Taskforce of the German Society of Ethnology', anonymously defended their action (Magisches Einsatzkommando der Deutschen Gesellschaft für Völkerkunde 1978). Historically, one of the heads was peculiar in that it had originally been part of an ethnographic collection in Łódź, Poland, which was stolen by Nazi Germany in 1942 and stored in Göttingen. This collection, obviously minus the tsantsa, was ultimately returned to Łódź in 2016 (cf. Cieślińska-Lobkowicz 2014; Herrmann 2018). What actually happened to the returned tsantsas in Ecuador in 1978 remains unknown.

The other listed repatriations cannot be considered in every detail here. They can largely be divided into two groups (cf. Fründt 2013: 324-33): those, usually small, with remains of one or two individuals, which have gone rather unnoticed, and those, usually larger, which have received more press coverage and have often also been covered in academic publications (table 1). The first group includes, for example, a return of two toi moko (tattooed preserved heads) to Aotearoa New Zealand in 2006 initiated by a curator of the Übersee-Museum in Bremen, and a Peruvian mummy that had come to Germany under unknown circumstances in 1985 and was seized by the police, who stored it at the Staatliches Museum für Völkerkunde 
(State Ethnological Museum) in Munich. The first group also includes the return of the remains of a Krenak man from Brazil, who died in Neuwied, Germany, in 1834 - he had lived there from 1818 as servant of a prince who had met him when travelling in Brazil (Roth 1995). His skull was returned by a Bonn anatomist upon a request from Brazil. So far, this repatriation has not been publicly documented except in newspaper articles (Akalin 2013).

The larger repatriations to Namibia, Australia, and Aotearoa New Zealand were all triggered by official requests from the respective government. Those to Australia and Aotearoa New Zealand were organized by 'state-sponsored repatriation programs' (Fründt 2013: 329). These larger repatriations are often covered in publications (see references in table 1) and will not be described in individual detail here.

\section{Statistical Evaluation of Repatriations from Germany}

The following analysis is based on available publications (cf. table 1) and, where these were absent, on press information or on unpublished data that were available to me either because I was involved in the organization of the repatriations myself or because I was given information by involved colleagues. ${ }^{1}$ For basic statistics, I generated an Excel spreadsheet with a row for every individual case included in the repatriations and with columns for returning institution and receiving community, the nature of the remains, names of collectors, year and place of acquisition, and names of individuals if available.

Until the end of April 2019, to my knowledge, human remains of a total of about 397 individuals were repatriated from Germany in 26 handovers. The number of individuals has to remain slightly vague, as in some cases, smaller bone fragments impeded their exact determination.

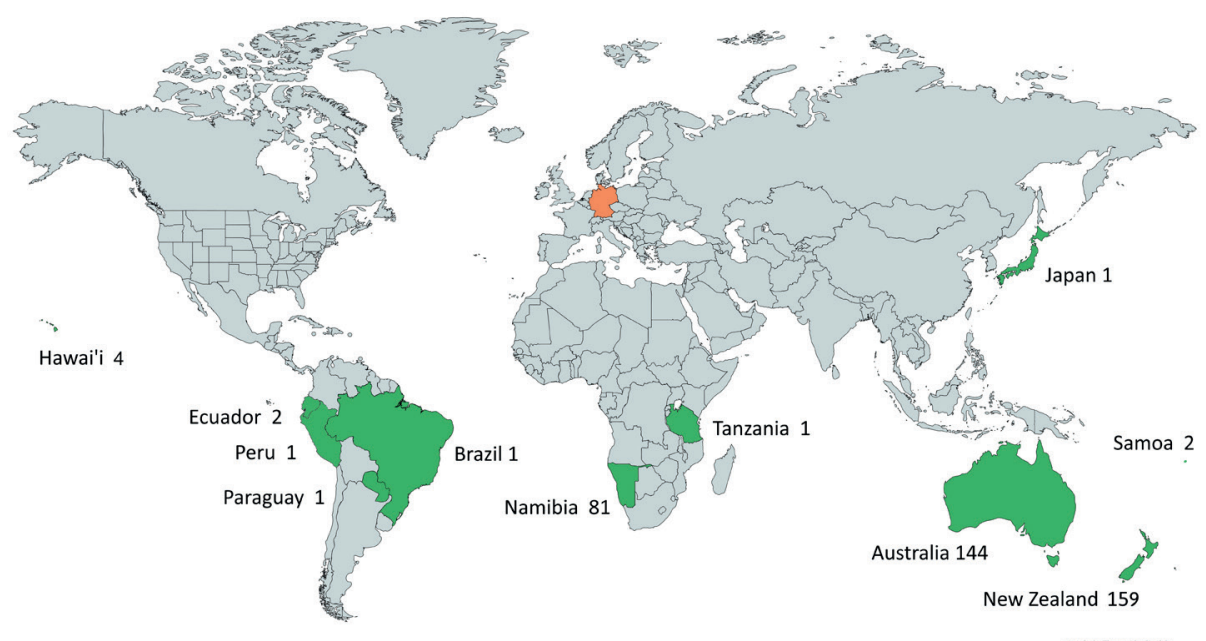

\section{Figure 1}

Figure 1 gives an overview of where the remains were returned to. Returning institutions are distributed all over Germany. Most repatriations came from Berlin (remains of 220 individuals), Dresden/Leipzig (80), and Bremen (47). Remains were returned by universities (251), museums (141), other institutions (4), and by two private persons (see table 1). The majority of remains were skulls or skull fragments without other skeletal parts (267 cases) and complete or incomplete skeletons (69 cases). In 39 cases, the remains were hair samples only. In at least 15 other cases, the remains included soft tissues, as in mummies (3), toi moko (8), shrunken heads (2) or scalps (2). Only in one case, this included soft tissue parts preserved in formalin (Koel-Abt and Winkelmann 2013). 
For 101 of the returned remains, published provenance research could be identified - defined for this purpose as research trying to clarify the origin of individual remains in preparation of, or related to, a repatriation of these remains. If we disregard the repatriations of 2019 as too recent to have produced relevant publications, this means that about half of the cases (94 out of 195) are documented in academic publications.

With the exception of three cases from the 1830s, one from 1861, and four from after 1930 , the year of the acquisition of remains - known more or less exactly in 354 cases ranges from 1872 to 1914 . The place or region of acquisition could be established in 320 cases. This also means, however, that in nearly one fifth of cases, the context of acquisition was so vague that it could not be narrowed down to a geographical place or region within the country of origin (when, for example, a skull was just labelled as stemming from 'Australia' or as being 'Maori' without further information). In 325 cases, at least one collector's name is known. This, however, was not necessarily the person who acquired remains directly.

So far, only in 43 cases, names could be attributed to individual remains. Of these, 33 are hair samples with recorded (European) names, all from one mission station in Victoria, Australia. The ten other cases include clear historical identities as in Mkwawa, the Hehe Chief from Tanzania; Kuêk or Joachim Quäck, the Krenak man from Brasil who died in Germany; and 'King Narcha' or Barry Clarke, a Ngadjon chief from Queensland (Govor 2000: 161). There is also Bob or Orininben, a Biyaygirri man from Queensland who died in 1884 in Chemnitz, while he was touring the USA and Europe as part of a 'circus troupe' led by a certain R. A. Cunningham (Poignant 2004: 144), where they were displayed as 'savages' and 'man-eaters'. There are two names, Uikabis and Nabnas, of local Damara women identifiable from court records of German Southwest Africa (Stoecker and Winkelmann 2018: 14). And one of the skulls returned to Namibia in 2014 may be connected to an Ovambo man named Omaruru, but this identification remains uncertain (Stoecker and Teßmann 2013).

In three cases, only 'colonial' names have survived: Nanny, a girl from Kangaroo Island with a Tasmanian mother (Winkelmann and Teßmann 2018); Harry Cocks, ${ }^{2}$ an Aboriginal man who died in a lunatic asylum in Adelaide (Winkelmann and Teßmann 2013); and Damiana, an Aché girl from Paraguay who died in Argentina (Koel-Abt and Winkelmann 2013). In the process of Damiana's reburial, the Aché gave her an Aché name, Kryygi, instead. Photographs have survived of four of these individuals (Mkwawa, Narcha, Orininben, and Damiana) while several painted portraits exist of Kuêk. Only the remains of two of these individuals (Mkwawa and Narcha) were actually returned to direct descendants.

Finally, there is scarce information on the fate of remains after repatriation. It can safely be assumed that many have been (re-)buried, but many do remain stored in local museums for the time being. This is true for all Namibian remains, which are stored at the National Museum in Windhoek (Förster 2013), and for poorly provenanced remains in Australia and Aotearoa New Zealand, which cannot yet be assigned to a local community (Pickering 2015: 468).

\section{Discussion}

\section{Interpretation of Statistical Findings}

As around 10,000 non-European human remains were stored in Berlin alone until after World War II (Stoecker and Winkelmann 2018), this number may realistically have been up to 20,000 for Germany as a whole. If this is true, 397 remains repatriated so far represent about two per cent of these collections. The former German colonies have clearly not been the only places from where German collectors acquired human remains (cf. Fig. 1). Some have also been acquired before the formalized start of German colonialism in 1884, but most of those which have been repatriated so far fall into the period of the German Empire (1871-1918). The geographical distribution confirms that German collectors established wide-spanning global networks for this purpose.

The numbers presented above confirm that the main scientific interest of the collectors was in skulls as a perceived defining feature of 'races' (Zimmerman 2001). Even when entire bodies or heads preserved in formalin were sent to Germany, the researchers often removed the soft tissue after dissection so that mostly just skulls survived in the collections (Stoecker and Winkelmann 2018; Winkelmann and Teßmann 2013). Dry skulls were easier to preserve and store than wet specimens, but large skull collections were obviously also a goal in itself. 
The fact that more than 300 mortal remains remained anonymous may be due to loss of documentation over the last 100 years and two world wars, but it also confirms the lack of interest of historical collectors and researchers in individual fates. Collectors were after examples of 'race', not after individual people - even in well-documented cases, the focus of the historical documentation was on place, 'race', age, and sex, not on individual identity (Winkelmann and Teßmann 2018).

\section{Standardization of Repatriation?}

It proved difficult to put all repatriations from Germany into one standardized table and to describe them by numbers. There has been no 'standard repatriation' and no standard protocol. This does not come as a surprise, given the variety of involved institutions and agencies, the different histories of individual collections, and the variety of historical backgrounds of source communities and of their relationship to Germany. The central German government has not played a big role in these processes, partly because the federal states (Länder) are responsible for 'cultural property' and for oversight of museums and universities, which leads to different policies and procedures and various degrees of autonomy among the involved institutions.

While it can be frustrating for Indigenous communities and their representatives to get information on ancestral remains in the 'jungle' of German institutions, I will not argue for centralized procedures and a central authority over these matters. It is nevertheless a step in the right direction that the German government has finally accepted its historical responsibility and installed the Fachbereich Kultur- und Sammlungsgut aus kolonialen Kontexten (Department for Cultural Goods from Colonial Contexts) as part of the Deutsches Zentrum Kulturgutverluste (German Lost Art Foundation) - not to centrally govern these activities but to support provenance research. Nor will I argue for a 'standard repatriation', but rather discuss two aspects of the variability of repatriations from Germany: provenance research and political context.

\section{Provenance Research}

In the context of (intended) repatriations, provenance research should not decide on whether or not to repatriate - that is a political and moral decision - but research is important to enable decisions on what to repatriate and to whom. Research is also important to elucidate the involvement of institutions and collectors in the 'colonial encounter'. Repatriation should rely on evidence of a colonial context of acquisition, but should not necessarily depend on the proof of a 'context of injustice', which is difficult to define anyway. Provenance research should also counteract colonial researchers' focus on 'race' and 'type' by 'rehumanizing' those who were objectified in the process.

As I have shown above, only about half of the repatriated remains were covered in academic publications including provenance research (table 1). It is difficult to say how much and what was done in the other cases. There is great variation as to the depth of historical research (archival research, sometimes even overseas) and the inclusion of anthropological methods like osteometry or invasive methods (isotope or DNA analysis). While this also depends on available funding, there is obviously no accepted standard of investigation before repatriation. Some have argued that historical research should take the lead over anthropological identification attempts (Pickering 2015: 470; Winkelmann 2018). Nevertheless, the expertise of (physical, biological or forensic) anthropologists is important to learn about the individual fate of the deceased (palaeopathology), and about what happened to the remains after death (taphonomy). In some cases, anthropological findings have also corroborated the violence of the colonial situation (see for example Skyring and Yu 2019; Stoecker and Winkelmann 2018).

Decisions are particularly difficult when historical research is fruitless, mostly due to loss of documentation. To base the attribution of a skull to a certain group of people merely on craniometry has proven hazardous (Ziegenfuß and Rücker 2018). It is also problematic for its closeness to the historical 'racial' classification of people based on skull morphology. In this situation of lost documentation, Freiburg researchers have resorted to strontium isotope and DNA analysis, the latter without success because of historical contamination with other 
DNA (Wittwer-Backofen et al. 2014). Isotope analysis of bones and teeth, which can relate the deceased to certain geological formations they lived on, can support an assumed origin but is open to interpretation, as geology does not follow country borders or ethnic groups, and similar geological formations may be found in different parts of the world.

As for DNA analysis, to my knowledge, this method only decided about repatriation in one of the 397 cases (Ziegenfuß and Rücker 2018). Some do advocate DNA as a means 'to precisely and accurately repatriate ancient remains' (Wright et al. 2018: 6), while others warn that this can be 'simply socially dangerous' (Pickering 2015: 470). Without discussing this further, I would hold that repatriation processes benefit more from historical plausibility than from statistical evidence and are more about social than biological identities. We need an open debate on what to do when historical evidence is lacking or when there is a serious mismatch between historical and biological data.

\section{Political context}

A primary motivation for repatriation is to bring ancestors home. As Henry Atkinson, a Wolithiga elder of Australia, writes, he asks to 'return my people home so their spirits can rest at last' (Atkinson 2010: 18). This respect for the wishes of the deceased and for the peace and dignity of the dead coincides with modern bioethical principles of informed consent, as in body donation for teaching and research purposes (Jones 2016). However, this basic motivation does not explain all the variability of repatriations, and it seems that political motivations also play a role.

There is obviously a variety of political contexts in which repatriations from Germany have taken place. Germany is not a settler colony in itself (which is why Bavarian or Westphalian skulls in anthropological collections will presumably never be 'repatriated' - they lack a colonial context), but Germany has been a colonial power. As the geographical distribution of returns shows (Fig. 1), however, the acquisition of human remains has not been limited to former German colonies and German researchers have benefitted from other colonial contexts.

Apart from the historical colonial context, much of the diversity of repatriations may be attributed to different agendas in today's political context. While the Australian and New Zealand governments, for example, organize repatriations to establish good relationships with the Indigenous population 'at home', several Namibian groups were driven by the German government's reluctance to acknowledge the genocide committed in Namibia between 1904 and 1908 , and by demanding material compensation from Germany. In this context, as Larissa Förster has argued,

the remains have become vehicles in a political movement that aims at the bigger picture, and not only seeks to explore the history of science or the history of museums and their complicity with colonialism, but addresses colonial violence and its redemption (Förster 2013).

In the North American context, Russell Thornton speaks of 'closure' rather than 'redemption' and writes in a similar vein: 'The repatriation process helps Native American groups to achieve some closure on traumatic events of their history' (Thornton 2002: 22). Repatriations cannot undo historical wrongs, but they seem to be a way of addressing them in contexts in which these wrongs are still relevant today. Repatriations therefore address historical as much as today's problems, like for example discrimination against Aboriginal people in Australian society or difficult living conditions of Herero and Nama in Namibia.

From a bioethical perspective, it could be argued that human remains should not be instrumentalized for today's political purposes. However, it would be naïve to think that historical colonial injustice and today's political situation can be separated. Human remains in colonial collections are deceased individuals, who deserve more respect and dignity than other collected objects, and, at the same time, witnesses and symbols of a history of injustice. As Gesine Krüger puts it, they 'stand for both life and death; they are 'charged' with history and memory and lend themselves, all the more, to the formation of identity, particularly in cases of fragmented colonial historiography' (Krüger 2010: 234). 
Collection curators may therefore become part of agendas that they do not immediately understand. I remember being the target of anger of the Namibian delegation when first presenting the remains and our research findings to them during the repatriation in 2011 partly because the German government was keeping a low profile at the time, as it did not want to discuss genocide or reparation with the Namibian delegation (Shigwedha 2016; Stoecker and Winkelmann 2018: 18). It also took me some time to understand why my contact with Australian Indigenous communities was mostly restricted to meeting some of them shortly at the time of the handover - the Australian government efficiently organizes these repatriations (including provenance research); their agenda is not to bring German institutions into contact with Indigenous communities but to support their own project of national reconciliation with the Indigenous population (Winkelmann 2020).

This is not to say that governments should not be involved in repatriations. Most repatriations have involved governments in one form or another (with the exception of the 1978 return). Government involvement is important, not least to have an official approval of who represents whom. It will nevertheless put reconciliation efforts on a broader basis, if more government-independent contacts between collecting institutions and source communities are sought, and if more collaborative approaches to provenance research can be realized.

So far, my own provenance research has not been very collaborative, which may be due to the agendas described above, but also to my reluctance to initiate contacts in a confusing field that was new to me as an anatomist. As far as I can see from the published sources (table 1), however, only one project so far has actually followed a truly collaborative approach to provenance research, i.e. in direct contact with source communities (and not just government agencies): Birgit Scheps-Bretschneider of the State Ethnographic Collections of Saxony has visited the Yawuru community in the Kimberley region of Western Australia and has researched the history of skeletons in the Saxonian state collections in close contact with members of this community (Skyring and Yu 2019). Such an approach to provenance research requires personal commitment, but also funding.

\section{Conclusion}

I do not want to promote a standard protocol for repatriation, but I suggest that interdisciplinary provenance research is a prerequisite for repatriation and that it should be published (allowing for ethical concerns on the side of the source communities). It is important research into the history of colonialism. And we would certainly have benefited from more published research when we began to research collections and to organize repatriations at Charité from 2010 onwards.

Collaborative approaches to provenance research should be the future (Förster 2016). More than guidelines and standardized policies, they may contribute to a lived reality of exchange between communities independent of, and in addition to, governmental efforts - an exchange that may better serve one of the central aims of repatriations, that is, reconciliation.

Received: 19 August 2019

Finally accepted: 20 February 2020

\section{Notes}

1 I thank Wiebke Ahrndt, Bremen, Claudia Andratschke, Hannover, Heike Kielstein, Halle, Michael Kraus, Göttingen, Philip Osten, Hamburg, and Birgit Scheps-Bretschneider, Leipzig, for providing additional information. I am also grateful to Hilary Howes, Sarah Fründt, and Holger Stoecker for their support.

2 The name "Harry Cocke" published by us in 2013 has proven to be a misreading from Hermann Klaatsch's handwritten diary. 


\section{References}

Akalin, C. (2013) 'Die Alte Anatomie der Universität wurde für 16,9 Millionen Euro saniert', Bonner General-Anzeiger, 20 March.

Atkinson, H. (2010) 'The meaning and values of repatriation', in Paul Turnbull and Michael Pickering (eds) The Long Way Home, 15-9, New York: Berghahn Books.

Ayau, E. H. and Keeler, H. (2017) 'Injustice, Human Rights, and Intellectual Savagery. A Review', in Larissa Förster and Sarah Fründt (eds) Human Remains in Museums and Collections. A Critical Engagement with the "Recommendations" of the German Museums Association (2013), 80-97, Berlin: Clio-online, www.hsozkult.de/debate/ id/diskussionen-3955.

Baer, M. and Schröter, O. (2001) Eine Kopfjagd - Deutsche in Ostafrika, Spuren kolonialer Herrschaft, Berlin: Ch. Links.

Brockmeyer, B. (2018) 'Menschliche Gebeine als Glaubensobjekte. Koloniale Kriegsbeutenahme, Vergleichspraktiken und Erinnerung seit dem späten 19. Jahrhundert', Werkstatt Geschichte, 77 47-64.

Cieślińska-Lobkowicz, N. (2014) 'Hunting and Diplomacy. Fate of Non-European Ethnographica Looted in Łódź in 1940 [in Polish]', Muzealnictwo, 55 216-33.

Förster, L. (2013) “"These skulls are not enough” - The Repatriation of Namibian Human Remains from Berlin to Windhoek in 2011'. darkmatter - in the ruins of imperial culture, Afterlives [11], http://www.darkmatter101.org/site/category/issues/11afterlives.

Förster, L. (2016) 'Plea for a More Systematic, Comparative, International and Longterm Approach to Restitution, Provenance Research and the Historiography of Collections', Museumskunde, 81 (1) 49-54.

Förster, L. and Stoecker, H. (2016) Haut, Haar und Knochen. Koloniale Spuren in naturkundlichen Sammlungen der Universität Jena, Weimar: VDG.

Förster, L., Henrichsen, D. and Stoecker, H. (2018) 'Re-individualising human remains from Namibia: colonialism, grave robbery and intellectual history', Human Remains and Violence, 4 (2) 45-66.

Fründt, S. (2013) 'Alle anders, alle gleich? Internationale Repatriierungsbewegungen', in Holger Stoecker, Thomas Schnalke and Andreas Winkelmann (eds) Sammeln, Erforschen, Zurückgeben? Menschliche Gebeine aus der Kolonialzeit in akademischen und musealen Sammlungen, 323-38, Berlin: Ch. Links.

Fründt, S. and Förster, L. (2018) 'Menschliche Überreste aus ehemals kolonisierten Gebieten in deutschen Institutionen. Historische Entwicklungen und zukünftige Perspektiven', in Marianne Bechhaus-Gerst and Joachim Zeller (eds) Deutschland postkolonial? Die Gegenwart der imperialen Vergangenheit, 505-31, Berlin: Metropol.

Govor, E. (2000) My Dark Brother - The Story of the Illins, a Russian-Aboriginal Family, Sydney: University of New South Wales Press.

Herewini, T. H. (2008) 'The Museum of New Zealand Te Papa Tongarewa (Te Papa) and the Repatriation of Köiwi Tangata (Mäori and Moriori Skeletal Remains) and Toi Moko (Mummified Maori Tattooed Heads)', International Journal of Cultural Property, 15 (4) 405-6. 
Herrmann, B. (2018) 'Doppelt sensibel. Die Ethnographische Sammlung Łódź als Zeugnis polnischer und deutscher Zeitgeschichte', in Anna-Maria Brandstetter and Vera Hierholzer (eds) Nicht nur Raubkunst! Sensible Dinge in Museen und universitären Sammlungen, 93-106, Göttingen: V\&R unipress.

Hulverscheidt, M. and Stoecker, H. (2018) ‘Erinnerungen an einen Schädel. Zum Umgang mit menschlichen Gebeinen im Völkerkundlichen Museum Witzenhausen', in AnnaMaria Brandstetter and Vera Hierholzer (eds) Nicht nur Raubkunst! Sensible Dinge in Museen und universitären Sammlungen, 205-20, Göttingen: V\&R unipress.

Hulverscheidt, M., Stoecker, H. and Hülsebusch, C. (2017) Die Spur des Schädels, Witzenhausen: Deutsches Institut für tropische und subtropische Landwirtschaft DITSL.

Jones, D. G. (2016) 'Searching for good practice recommendations on body donation across diverse cultures', Clinical Anatomy, 29 55-9.

Koel-Abt, K. and Winkelmann, A. (2013) 'The identification and restitution of human remains from an Aché girl named "Damiana": an interdisciplinary approach', Annals of Anatomy, 195 393-400.

Krüger, G. (2019) 'Moving bones. Unsettled histories in South Africa and the return of Sarah Baartman', in Sebastian Jobs and Alf Lüdtke (eds) Unsettling history: archiving and narrating in historiography, 233-50, Frankfurt/Main: Campus.

Kunst, B. and Creutz, U. (2013) 'Geschichte der Berliner anthropologischen Sammlungen von Rudolf Virchow und Felix von Luschan', in Holger Stoecker, Thomas Schnalke and Andreas Winkelmann (eds) Sammeln, Erforschen, Zurückgeben?, 69-83, Berlin: Ch. Links.

Magisches Einsatzkommando der Deutschen Gesellschaft für Völkerkunde (1978) 'Dokumentation SHUAR', Trickster, 1 10-26.

Möller, D. (2015[2008]) Die Geschichte der Anthropologischen Sammlung in Freiburg Entstehung, Zusammenführung, Verlust, Marburg: Tectum.

Pickering, M. (2015) 'Rewards and Frustrations - Repatriation of Aboriginal and Torres Strait Islander Ancestral Remains by the National Museum of Australia', in Conal McCarthy (ed) The international handbooks of museum studies: museum practice, Hoboken: Wiley.

Poignant, R. (2004) Professional Savages: Captive Lives and Western Spectacle, New Haven: Yale University Press.

Roth, H. J. (1995) Prinz Max zu Wied, Leben und Werk, Begleitschrift zur Ausstellung im Landschaftsmuseum Hachenburg 1994, Montabaur: Verlag der Museen des Westerwaldkreises.

Schlott, C. (2018) 'Zur Provenienz der anthropologischen Sammlung des Museums für Völkerkunde Dresden', in Larissa Förster, Iris Edenheiser, Sarah Fründt and Heike Hartmann (eds) Provenienzforschung in ethnografischen Sammlungen der Kolonialzeit. Positionen in der aktuellen Debatte, 133-42, Berlin: HumboldtUniversität, http://edoc.hu-berlin.de/provenienzforschung

Schrenk, F., Kuper, A., Rahn, A. M. and Eiser, I. (2018) 'Menschen in Sammlungen. Geschichte verpflichtet', in Anna-Maria Brandstetter and Vera Hierholzer (eds) Nicht nur Raubkunst! Sensible Dinge in Museen und universitären Sammlungen, 45-61, Göttingen: V\&R unipress. 
Schultz, E. (1911) Letter (Apia, Samoa) to Felix von Luschan, Berlin, 17 May. Archive of the Ethnologisches Museum Berlin: Acta betreffend die Erwerbung anthropologischen Materials 4 (1910-1914) Pars I B 39.

Shigwedha, V. A. (2016) 'The return of Herero and Nama bones from Germany: the victims' struggle for recognition and recurring genocide memories in Namibia', in Jean-Marc Dreyfus and Élisabeth Anstett (eds) Human remains in society - Curation and exhibition in the aftermath of genocide and mass-violence, Manchester: Manchester University Press.

Skyring, F. and Yu, S. (2019) 'Wanggajarli Burugun, We are coming home - Gwarinman Project (Report to Council of Broome, 18 April 2019)', http://broome.infocouncil.biz/ Open/2019/04/CO_18042019_MIN_1584_AT_files/CO_18042019_MIN_1584_AT_ Attachment 5748 1.pdf

Stoecker, H. and Teßmann, B. (2013) 'Namibische Gebeine in Berlin - Methoden und Recherchewege der Provenienzforschung', in Holger Stoecker, Thomas Schnalke and Andreas Winkelmann (eds) Sammeln, Erforschen, Zurückgeben?, 199-223, Berlin: Ch. Links.

Stoecker, H. and Winkelmann, A. (2018) 'Skulls and skeletons from Namibia in Berlin Results of the Charité Human Remains Project', Human Remains and Violence, 4 (2) 5-26.

Te Papa Museum (2011) 'European Repatriation - Background Information for Press Releases - 29 April to 12 May 2011', https://www.tepapa.govt.nz/sites/default/files/ european repatriation_background info for_press releases-29 april to 12 may 2011.pdf.

Thornton, R. (2002) 'Repatriation as healing the wounds of the trauma of history: cases of Native Americans in the United States of America', in Cressida Fforde, Jane Hubert and Paul Turnbull (eds) The dead and their possessions: Repatriation in principle, policy and practice, 17-24, London: Routledge.

Turnbull, P. (2017) Science, Museums and Collecting the Indigenous Dead in Colonial Australia, Palgrave Studies in Pacific History, Cham: Palgrave Macmillan.

von Luschan, F. (1911) Letter (Berlin) to Erich Schultz (Kaiserlicher Ober-Richter, stellvertretender Gouverneur von Samoa), 22 July. Archive of the Ethnologisches Museum Berlin: Acta betreffend die Erwerbung anthropologischen Materials 4 (1910-1914) Pars I B 39.

Winkelmann, A. (2012) 'Zeugen zweier Geschichten - Die Charité gab Schädel aus der Kolonialzeit nach Namibia zurück', Deutsches Ärzteblatt, 109 (15) A754-5.

Winkelmann, A. (2018) 'Die Schwierigkeiten der Provenienzforschung', in Gerhard Ziegenfuß and Helmut Rücker (eds) Ein Schädel aus Namibia - Erhobenen Hauptes zurück nach Afrika, 116-20, Ahlen: Anno Verlag.

Winkelmann, A. (2020) 'Wilhelm Krause's collections - journeys between Australia and Germany', in Cressida Fforde, C. Timothy McKeown, and Honor Keeler (eds) The Routledge Companion to Indigenous Repatriation: Return, Reconcile, Renew, 46983, London: Routledge.

Winkelmann, A. and Stoecker, H. (2014) 'Rückgabe von Schädeln und Skeletten an Namibia - Überreste einer fragwürdigen "Rasseforschung"', Deutsches Ärzteblatt, 111 (18) A792-3. 
Winkelmann, A. and Teßmann, B. (2013) “... und gewinne die Leiche” - Zur Geschichte eines australischen Skeletts in der Berliner Anatomischen Sammlung', in Holger Stoecker, Thomas Schnalke and Andreas Winkelmann (eds) Sammeln, Erforschen, Zurückgeben?, 184-98, Berlin: Ch. Links.

Winkelmann, A. and Teßmann, B. (2018) 'Identification and return of a skull from Tasmania in the Berlin anatomical collection', Journal of Biological and Clinical Anthropology, 75 (1) $39-47$.

Wittwer-Backofen, U., Kastner, M., Möller, D., Vohberger, M., Lutz-Bonengel, S. and Speck, D. (2014) 'Ambiguous provenance? Experience with provenance analysis of human remains from Namibia in the Alexander Ecker collection', Journal of Biological and Clinical Anthropology, 71 (1-2) 65-86.

Wright, J. L. et al. (2018) 'Ancient nuclear genomes enable repatriation of Indigenous human remains', Science Advances, 4 (12) eaau5064.

Ziegenfuß, G. and Rücker, H. (2018) Ein Schädel aus Namibia - Erhobenen Hauptes zurück nach Afrika, Ahlen: Anno Verlag.

Zimmerman, A. (2001) Anthropology and antihumanism in imperial Germany, Chicago: University of Chicago Press.

\section{Biography}

Andreas Winkelmann is a medical doctor by training and holds an additional MSc. degree in medical anthropology. He teaches anatomy at Brandenburg Medical School, Germany (since 2015). He has published on the history and ethics of anatomy - with a focus on the times of National Socialism - and chairs the committee for ethics and medical humanities of the International Federation of Associations of Anatomists. From 2010 to 2013 he headed the Charité Human Remains Project in Berlin, which conducted research on the provenance of human remains from Namibia, Australia, Aotearoa New Zealand and Paraguay in colonial collections and organised several repatriations. 